\title{
Heavy metals concentration in native edible fish at upper Meghna River and its associated tributaries in Bangladesh: a prospective human health concern
}

\author{
Md. Jahangir Sarker ${ }^{1}\left(\mathbb{D} \cdot\right.$ Amin Ullah Polash $^{1} \cdot$ Md. Ariful Islam $^{1} \cdot$ Nazmun Naher Rima $^{1} \cdot$ Tania Farhana $^{1}$
}

Received: 5 May 2020 / Accepted: 27 August 2020 / Published online: 10 September 2020

(c) Springer Nature Switzerland AG 2020

\begin{abstract}
The study aimed to determine the concentration $\left(\mathrm{mg} \mathrm{kg}^{-1}\right)$ of selected heavy metals including chromium (Cr), copper (Cu), zinc $(\mathrm{Zn})$, arsenic $(\mathrm{As})$, lead $(\mathrm{Pb})$ and cadmium $(\mathrm{Cd})$ along with possible human health risk from 9 popular freshwater native edible fishes (Anabas testudineus, Channa punctatus, Gagata youssoufi, Heteropneustes fossilis, Mastacembelus armatus, Mystus tengara, Ompok pabda, Puntius ticto and Xenentodon cancila) in ranges at upper Meghna River and its associated tributaries, Bangladesh, during November 2018. Inductively coupled plasma-mass spectrometer (ICP-MS) was used to measure the average concentration of selected metals that followed the trends of $\mathrm{Zn}(1.42)>\mathrm{Cr}(1.31)>\mathrm{Cu}(0.92)>\mathrm{Pb}$ (0.54) $>\mathrm{Cd}(0.51)>\mathrm{As}(0.47) \mathrm{mg} \mathrm{kg}^{-1}$. Although the mean total content of $\mathrm{As}\left(0.47 \mathrm{mg} \mathrm{kg}^{-1}\right)$ was least quantities, G. youssoufi $\left(0.87 \mathrm{mg} \mathrm{kg}^{-1}\right)$ accumulated the maximum concentration. The results revealed that all the heavy metals were lower than the permissible limits stated by national (e.g., MOFL) and international (e.g., FAO, WHO, EU, USEPA) agencies except for $\mathrm{Cr}$ and $\mathrm{Pb}$. Furthermore, the assessed heavy metals concentration at the selected areas was comparatively lower than its nearby urban and estuarine areas of the river. Estimated daily intake, target hazard quotient (THQ) and carcinogenic risk (CR) were analyzed to interpret the effect of health risk. The THQ values were $<1$ which denoted no health risk to neither children nor adult. In addition, the $C R$ value was $\leq 10^{-4}$ for children, whereas the amount was always below $10^{-4}$ for adult that denoted no major deleterious effects to the consumers. However, the prolonged exposure to heavy metals might cause risk to both ages especially to the younger individuals.
\end{abstract}

Keywords Carcinogenic risk · Health hazard · Heavy metals concentrations · Meghna River · Native freshwater fish

\section{Introduction}

Heavy metals concentration in the aquatic environment has drawn a prime concern increasingly in Bangladesh due to becoming a 3rd world country $[1,2]$ as well as for lethal toxicity, innate persistence, non-biodegradability and accumulative nature [3]. Anthropogenic activities, rapid industrial development (point source), agricultural runoff (non-point source), etc., produce trace metals which subsequently enter to the aquatic habitats and cause a significant hazardous impact on the dwelling organisms
$[4,5]$. The aquatic organisms such as fish and invertebrates can be contaminated through the untreated or poorly treated both point and non-point sources of pollutants. For instance, surface water pollution, disposing agricultural and industrial effluents, applying chemical fertilizers, pesticides are the major sources of heavy metals contamination [6]. Although some trace metals are essential to maintain human body metabolism, they can be toxic at higher concentrations. In addition, some are highly toxic in nature such as $\mathrm{Cd}, \mathrm{Pb}$ and $\mathrm{Hg}$ [7]. Due to exceeding the permissible optimal concentrations of these metals, they

Md. Jahangir Sarker, mjsarker@nstu.edu.bd| 'Department of Fisheries and Marine Science, Noakhali Science and Technology University, Noakhali 3814, Bangladesh. 
gradually dilute in water and deposit to sediment columns and subsequently accumulate into fish body through feeding the benthic and pelagic species-contaminated water [8] and make differences between the uptake and elimination rates [9]. It also can be assimilated by several ways, for example, up-taking particulate solid suspended matters from water, ion exchange, adsorption on tissue and skin surfaces [10]. As a result, these contaminants assimilate to human body through consumption and adversely affect our health [11]. For instance, $\mathrm{Cr}$ causes nephritis, anuria and extensive lesions in the kidney [12].

On the other hand, fish is widely consumed due to its lipids, proteins, vitamins, minerals contents and most importantly the presence of long-chain omega-3 polyunsaturated fatty acids (PUFAs) [13]. Apart from the longchain omega-3 PUFAs, numerous other fish components have been found to have positive effects on human health [14]. For example, the nutritive components of fish muscles can be effective to protect against several coronary heart diseases, stroke and other health benefits [13]. Furthermore, fish protein with superior quality contains all the essential amino acids, dietary vitamins and micro-minerals, such as $Z n, F e, C a, P$, vitamins $A, D, E$ and several $B$ vitamins (B3, B6 and B12) [15].

The Meghna River supplies an influential cascade of numerous biological species and the financial trends, where the local people are directly or indirectly associated with the commercial capture fishery. Additionally, about 3500 tons of selective fish species actively contributes to the commercial fish marketing channel per year [16]. Nevertheless, in the recent years the rivers receive a bulk amount of toxic materials disposed from numerous milling and processing industries and drainage waterlines, polluting most rivers in Bangladesh [17]. Ideally the poorly treated industrial effluents, discharged and wastage function as potential contributor for trace metals in the Meghna River.

The heavy metals contamination in water and sediment at the Meghna River was performed by Hasan et al. [18]. Ahmed et al. [16] studied the bioaccumulation and trace metals concentration in commercially important marine fish at the estuarine areas of Meghna River. However, no research has been investigated on the upper Meghna River and its associated tributaries to date emphasizing on the most popular freshwater native fishes, although it provides a bulk quantity of aquatic foodstuffs to the coastal people especially the tributaries closely linked to the territory people. Therefore, we aimed to assess some toxic trace metal (e.g., Cr, Cu, Zn, As Pb and Cd) concentrations of some popular native freshwater fishes from their edible muscle. We compared also the measured contaminations level with worldwide accepted standard and other findings along with possible health risk assessment both carcinogenic and non-carcinogenic due to dietary consumption of these fish species for various age groups dwelling adjacent to the river and its tributaries.

\section{Materials and methods}

\subsection{Study area}

The research was conducted at upper Meghna River and its associated tributaries of the coastal area of Chandpur district conjoint with Padma River (S1), Chittagong division, flowed downward to Mehendiganj Upazila of Barisal district Bangladesh (Fig. 1). It is one of the most important rivers in Bangladesh which lies between the latitude $22^{\circ}$ $38^{\prime} 35^{\prime \prime} \mathrm{N}$ and longitude $90^{\circ} 48^{\prime} 57^{\prime \prime} \mathrm{E}$ in Bangladesh part by adjoining the Surma and Kushiyara Rivers originating from the hilly regions of eastern India as Barak River through different cities and municipalities.

\subsection{Sample collection}

A total of 72 fish specimens belonging to 9 species, namely Climbing perch (A. testudineus), Spotted snakehead ( $C$. punctatus), Sisorid catfish (G. youssoufi), Stinging catfish ( $H$. fossilis), Zig-zag eel (M. armatus), Tengara (M. tengara), Pabdah catfish (O. pabda), Ticto barb (P. ticto) and Asian freshwater needlefish (X. cancila) (Table 1) were collected from 10 stations ( $S 1$ to $S 10$ ) at the upper Meghna River and its associated tributaries during November 3-4, 2018 (Fig. 1). The stations S6, S7, S8 and S9 were located at the branch of Meghna River. A small mechanized boat was taken, and cast net was thrown to collect fish species. Immediately after harvesting, fish specimens were washed thoroughly with freshwater to remove the muds or other fouling substances and put in the clean polythene bag and preserved in ice boxes at around $-1^{\circ} \mathrm{C}$. After that, specimens were brought for laboratory analysis and preserved at $-20^{\circ} \mathrm{C}$. Specimens were allowed to reach room temperature, and non-edible parts (fins, guts, scales, etc.) were removed by steam cleaned stainless steel knife. The edible portion of fish samples (muscle) was thoroughly rinsed with deionized water and chopped into thin chunks $(1.5-3.0 \mathrm{~cm})$ by sharp knife on sterilized polythene sheet. Then, the prepared samples were air-dried to remove the extra water.

\subsection{Sample preparation and analysis}

$0.25 \mathrm{mg}$ of muscle specimens was taken from each specimen and weighted using an electric balance. A digestion reagent was made by adding $5 \mathrm{~mL}$ of distilled water, $5 \mathrm{~mL}$ of nitric acid $\left(\mathrm{HNO}_{3}, 65 \%\right)$ and $2 \mathrm{~mL}$ of hydrogen peroxide $\left(\mathrm{H}_{2} \mathrm{O}_{2}, 30 \%\right)$. Then, the digestion reagent and 

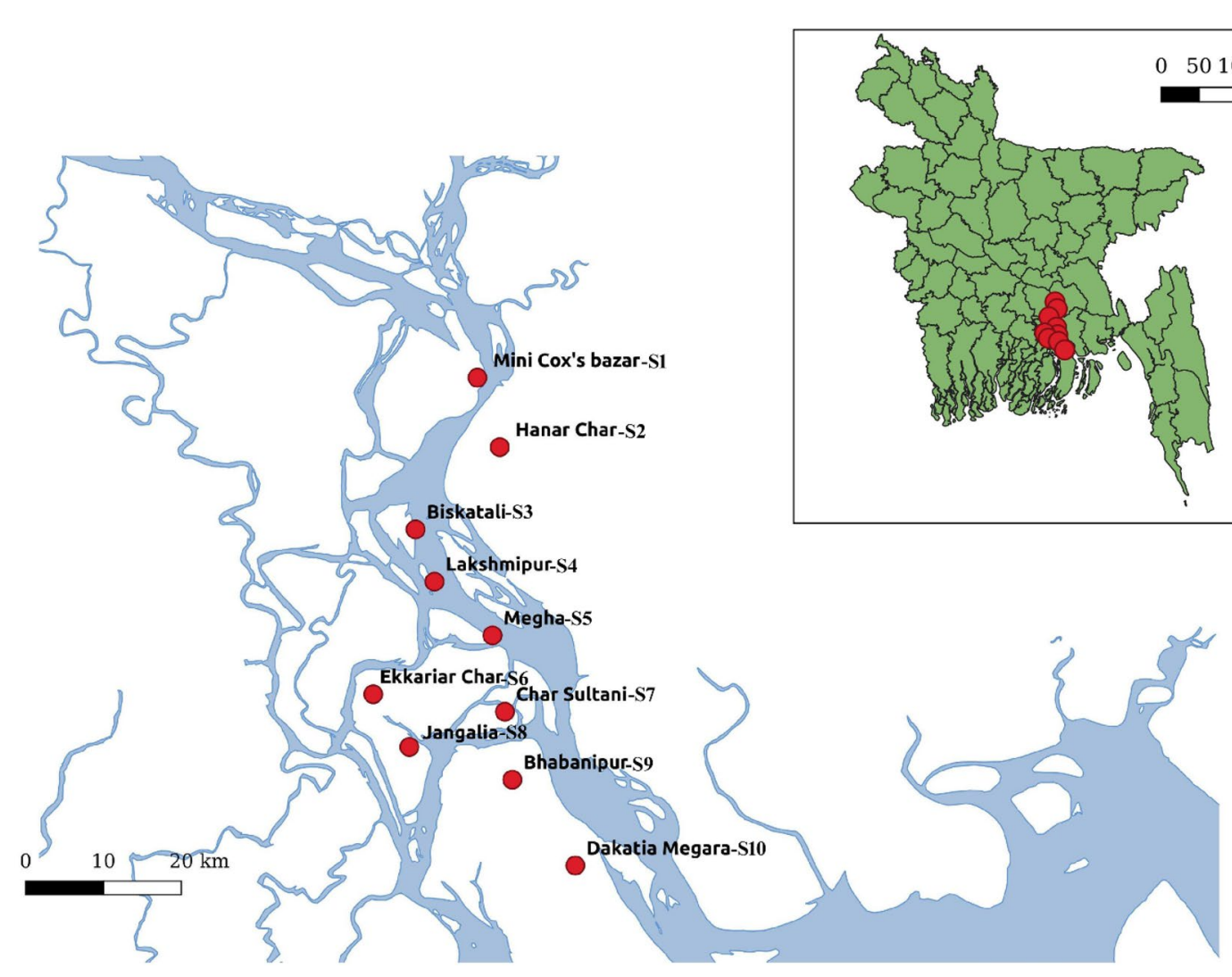

Fig. 1 The map shows study areas where red-colored filled circles show sampling stations

Table 1 Weight-length range and feeding habits of collected fish specimens

\begin{tabular}{|c|c|c|c|c|c|}
\hline $\begin{array}{l}\text { Scientific name of } \\
\text { the species }\end{array}$ & Common name & $\begin{array}{l}\text { No. of samples } \\
\text { analyzed }\end{array}$ & Weight (g) range & Length $(\mathrm{cm})$ range & Feeding habits \\
\hline A. testudineus & Climbing perch & 8 & $45-60$ & $11-12$ & Carnivorous \\
\hline C.punctatus & Spotted snakehead & 8 & $60-80$ & $15-18$ & Carnivorous \\
\hline G. youssoufi & Sisorid catfish & 8 & $11-14$ & $4-5$ & Carnivorous \\
\hline H. fossilis & Stinging catfish & 8 & $70-90$ & $18.5-20$ & Carnivorous \\
\hline M. armatus & Zig-zag eel & 8 & $20-45$ & $13-17$ & Omnivores \\
\hline M. tengara & Tengara mystus & 8 & $15-20$ & $11-12$ & Carnivorous \\
\hline O.pabda & Pabdah catfish & 8 & $90-100$ & $20-22$ & Omnivores \\
\hline P. ticto & Ticto barb & 8 & $20-45$ & $10-11$ & Omnivores \\
\hline X. cancila & Asian freshwater needlefish & 8 & $15-50$ & $15-28$ & Carnivorous \\
\hline
\end{tabular}

balanced muscle specimens were kept in a Teflon vessel. Microwave (1000 W, Berghof-MWS2, Berghof speedwave, Eningen, Germany) was used to digest the specimens thoroughly overnight. After a complete digestion, $0.42 \mu \mathrm{m}$ pore sized Whatman membrane filter paper was used to filter the solution pulp and kept in $50 \mathrm{~mL}$ polypropylene centrifuge tubes (Nalgene, New York).

Inductively coupled plasma mass spectrometer (ICPMS, Agilent 7700 series) was conducted to analyze the selected trace metals. The calibration curve was prepared by using Multi-element Standard XSTC-13 (Spex Certi Prep, Metuchen, USA) solutions. A desired calibration precision ( $s d v<20 \%$ ) was used with certified reference materials to assure the analytical assessment. 


\subsection{Statistical analysis}

Multivariate analysis was performed by using IBM SPSS (Version: 20.0) and PAST (Version: 4.02). Pearson correlation coefficients were used to compare the selected metals among different fish species.

\section{Calculations}

\subsection{Estimated daily intakes (EDI) of human}

Basically, the evaluation of human health hazards has been adopted due to the consumption of metals containing in the foodstuffs [19]. Estimated daily intakes (EDIs) are analyzed on the basis of the metals concentration levels in fish muscles and daily consumption of fish [20]. This equation is followed by US EPA (United States Environmental Protection Agency) [21-23] and some other studies [24, 25]:

$\mathrm{EDI}=\left(C * F_{\text {intake }}\right) / \mathrm{dw}$

where $C$ is the heavy metals concentration in fish $\left[\mathrm{mg} \mathrm{kg}^{-1}\right.$, dry weight $(\mathrm{dw})] . F_{\text {intake }}$ is the average food consumption $\left(g\right.$ person ${ }^{-1}$ ) followed by FAOSTAT (Food and Agriculture Organization of the United Nations) database (period 2013). Fish consumption rate for children and adult resident is $52.5 \mathrm{~g} \mathrm{day}^{-1}, 55.5 \mathrm{~g} \mathrm{day}^{-1}$, respectively [19]. And Bw is the body weight for children (15 kg) and adult (65 kg) $[26,27]$.

\subsection{Target hazard quotient (THQ) for non-carcinogenic risk}

Target hazard quotient is analyzed to identify the potential risk level due to exposure of contaminants. The calculation is made using the following equation $[19,28,29]$.

$\mathrm{THQ}=\left(E_{\mathrm{d}} * E_{\mathrm{p}} * \mathrm{EDI}\right) /(\mathrm{RfD} * \mathrm{MT}) * 10^{-3}$

where EDI is the estimated daily intake and RfD is the oral reference dose $\left(\mathrm{mg}\right.$ person ${ }^{-1}$ day $\left.^{-1}\right)$; RfDs are based on 1.5, 0.04, 0.3, 0.0003, 0.00035 and 0.0005 for $\mathrm{Cr}, \mathrm{Cu}, \mathrm{Zn}$, As, $\mathrm{Pb}$ and $\mathrm{Cd}$, respectively [30]. $\mathrm{E}_{\mathrm{d}}$ is exposure duration (over lifetime of a human 65 years) [26, 27]; $\mathrm{E}_{\mathrm{p}}$ is exposure frequency ( 365 days year ${ }^{-1}$ ); EDI is estimated daily intake per metal content; and MT is the meantime for non-carcinogens $\left(E_{\mathrm{d}} \times E_{\mathrm{p}}\right)$.

If the $T H Q<1$, it indicates no non-carcinogenic risk effects [31], whereas if it rises $\geq 1$, there is a potentiality to health risk [32]; therefore, associated and defensive precaution ought to be adopted.

\subsection{Carcinogenic risk (CR)}

CR is determined to assess the possibility of forming cancer cell in human body over a lifetime expression to those powerful carcinogens [33]. The acceptable range for carcinogenic risk is between $10^{-4}$ (over a human lifetime, the risk of developing cancer is 1 in 10,000) and $10^{-6}$ (over a human lifetime, the risk of developing cancer is 1 in 1000000$)[21-23,34-36]$. If $C R$ values $>10^{-4}$, it infers the feasible probability of carcinogenic risk [30, 37, 38]. The $C R$ is measured by multiplying the carcinogenic slope factor of the metal contents $[39,40]$, and the equation is as follows [41, 42]:

$\mathrm{CR}=\left(E_{\mathrm{d}} * E_{\mathrm{p}} * \mathrm{EDI} * \mathrm{CSF}\right) /(\mathrm{MT}) * 10^{-3}$

where CSF is the oral slope factor of carcinogens $\left(\mathrm{mg} \mathrm{kg}^{-1} \mathrm{day}^{-1}\right)$ adopted from the Integrated Risk Information System supplied by USEPA [30,37]; CSF values are available solely for $\mathrm{As}(1.5), \mathrm{Pb}(0.0085)$ and $\mathrm{Cd}(6.3)$ [21-23]. The possibility of forming cancer for a consumer will be $>1$ over 100,000 , when CR values are above $10^{-5}$ $[19,43]$.

\section{Results and discussion}

\subsection{Heavy metals concentration in the selected freshwater native fishes}

Six metals, $\mathrm{Zn}, \mathrm{Cr}, \mathrm{Cu}, \mathrm{Pd}, \mathrm{Cd}$ and $\mathrm{As}$, in nine indigenous freshwater edible fish species from the upper Meghna River (S1, S2, S3, S4, S5 and S10) and its branches (S6, S7, S8 and S9) (Fig. 1) were considered in this study. As kidneys, liver, guts and gills are generally omitted in diet as part of food habits in Bangladesh, only fish muscle (edible chunk) was considered to assess the heavy metals concentration. The assessment of heavy metals concentration in food ingredients is crucial as it imparts the environmental defilement intimated to human health hazard [14]. The hierarchy of trace metals concentrations trends is as follows: $\mathrm{Zn}(1.42)>\mathrm{Cr}(1.31)>\mathrm{Cu}(0.92)>\mathrm{Pb}$ $(0.54)>\mathrm{Cd}(0.51)>$ As $(0.47)\left(\mathrm{mg} \mathrm{kg}^{-1}\right)$, respectively (Table 2). The average concentrations of metals at stations selected in the branch River of Meghna did not show wider variation compared to the stations selected in its main River. However, a positive correlation was analyzed at $p<0.05$ significant level between $\mathrm{Cu}-\mathrm{Pb}(0.56)$ and $\mathrm{Pb}-\mathrm{Cd}(0.54)$. In contrast, $\mathrm{Pd}-\mathrm{Zn}(-0.36)$ was negatively correlated with each other (Table 3 ). 


\subsection{Chromium (Cr)}

Among all the trace metals, individually $\mathrm{Cr}$ was measured as the maximum in $P$. ticto $\left(1.91 \mathrm{mg} \mathrm{kg}^{-1}\right)$ that exceeded both the national $[44]$ and international $[45,46]$ guidelines (Table 2). The mean concentration of $\mathrm{Cr}$ in different fish species was as follows: $P$. ticto $\left(1.91 \mathrm{mg} \mathrm{kg}^{-1}\right)>G$. youssouf $\left(1.47 \mathrm{mg} \mathrm{kg}^{-1}\right)>M$. tengara $\left(1.35 \mathrm{mg} \mathrm{kg}^{-1}\right)>H$. fossilis $\left(1.30 \mathrm{mg} \mathrm{kg}^{-1}\right)>0$. pabda $\left(1.28 \mathrm{mg} \mathrm{kg}^{-1}\right)>$ A. testudineus $\left(1.27 \mathrm{mg} \mathrm{kg}^{-1}\right)>C$. punctatus $\left(1.12 \mathrm{mg} \mathrm{kg}^{-1}\right)>M$. armatus $\left(1.05 \mathrm{mg} \mathrm{kg}^{-1}\right)>X$. cancila $\left(1.01 \mathrm{mg} \mathrm{kg}^{-1}\right)$ (Fig. 2). The least amount of $\mathrm{Cr}$ was estimated on $X$. cancila $\left(1.01 \mathrm{mg} \mathrm{kg}^{-1}\right)$.
The maximum tolerance range for $\mathrm{Cr}$ is $0.1-1.0 \mathrm{mg} \mathrm{kg}^{-1}$ set by FAO (Food and Agriculture Organization) [45], WHO (World Health Organization) [46] and MOFL (Ministry of Fisheries and Livestock) [44] (Table 2). The concentration range of $\mathrm{Cr}$ was assessed between 0.62 and $1.19 \mathrm{mg} \mathrm{kg}^{-1}$ in Meghna Estuary, Noakhali [16], and average $0.32 \mathrm{mg} \mathrm{kg}^{-1} \mathrm{Cr}$ was recorded from demersal marine fish in another Meghna Estuarine areas of Bhola [47]. Furthermore, $\mathrm{Cr}$ concentration range was estimated between $1.1-1.5 \mathrm{mg} \mathrm{kg}^{-1}$ on C. punctatus; $1.5-2.1 \mathrm{mg} \mathrm{kg}^{-1}$ on H. fossilis; and $1.4-2.5 \mathrm{mg} \mathrm{kg}^{-1}$ on T. fasciata in Turag, Buriganga and Shitalakha River, respectively, which highly aligned
Table 2 A comparison among dietary intakes of trace elements from collected fish samples with the corresponding maximum tolerable daily intake (MTDI) and guidelines
Table 3 Pearson correlation matrix between heavy metals in the freshwater native fish specimens

\begin{tabular}{|c|c|c|c|c|c|}
\hline \multirow[t]{2}{*}{$\begin{array}{l}\text { Trace } \\
\text { ele- } \\
\text { ments }\end{array}$} & \multirow[t]{2}{*}{$\begin{array}{l}\text { Mean con- } \\
\text { centration } \\
\left(\mathrm{mg} \mathrm{kg}^{-1}\right)\end{array}$} & \multirow[t]{2}{*}{ Guidelines ( $\mathrm{mg} \mathrm{kg}^{-1}$ ) } & \multicolumn{2}{|c|}{$\begin{array}{l}\text { Estimated daily } \\
\text { intake }(E D I) \\
\left(\mathrm{mg} \mathrm{day}^{-1} \text { person }^{-1}\right)\end{array}$} & \multirow[t]{2}{*}{$\begin{array}{l}\text { Maximum tolerable daily } \\
\text { intake (MTDI) (mg day }{ }^{-1} \text { per- } \\
\text { so }^{-1} \text { ) }\end{array}$} \\
\hline & & & Children & Adult & \\
\hline $\mathrm{Cr}$ & 1.31 & $0.1^{\mathrm{a}}, 1.0^{\mathrm{b}}, 0.15^{\mathrm{c}}$ & 0.00457 & 0.00104 & $0.23[69]$ \\
\hline $\mathrm{Cu}$ & 0.92 & $5.0^{b}, 70.0^{c}$ & 0.00320 & 0.00073 & 35 [69] \\
\hline $\mathrm{Zn}$ & 1.42 & $30.0^{c_{1}^{*}}$ & 0.00496 & 0.00113 & $60[70]$ \\
\hline As & 0.47 & $1.0^{\mathrm{a}}, 5.0^{\mathrm{b}}, 1.0^{\mathrm{c}}$ & 0.00166 & 0.00038 & $0.13[71]$ \\
\hline $\mathrm{Pb}$ & 0.54 & $0.5^{a, c}, 0.3^{b}$ & 0.00189 & 0.00043 & $0.25[65]$ \\
\hline $\mathrm{Cd}$ & 0.51 & $0.1^{\mathrm{a}, \mathrm{c}}, 0.25^{\mathrm{b}}$ & 0.001664 & 0.000380 & $0.07[69]$ \\
\hline
\end{tabular}

${ }^{\mathrm{a}}[46] ;{ }^{\mathrm{b}}[44] ;{ }^{\mathrm{c}}[45] ;{ }^{*}[60]$

\begin{tabular}{lllllll}
\hline Metals & $\mathrm{Cr}$ & $\mathrm{Cu}$ & $\mathrm{As}$ & $\mathrm{Zn}$ & $\mathrm{Pb}$ & $\mathrm{Cd}$ \\
\hline $\mathrm{Cr}$ & 1 & & & & & \\
$\mathrm{Cu}$ & 0.43 & 1 & & & & \\
$\mathrm{Zn}$ & 0.02 & -0.41 & 1 & & & \\
$\mathrm{As}$ & 0.35 & -0.21 & -0.01 & 1 & 1 & \\
$\mathrm{~Pb}$ & -0.26 & $* \mathbf{0 . 5 6}$ & -0.24 & $-\mathbf{0}^{*} \mathbf{0 . 3 6}$ & & \\
$\mathrm{Cd}$ & 0.15 & 0.15 & 0.34 & 0.21 & $* \mathbf{0 . 5 4}$ & 1 \\
\hline
\end{tabular}

Significant values are at $* P<0.05$ level

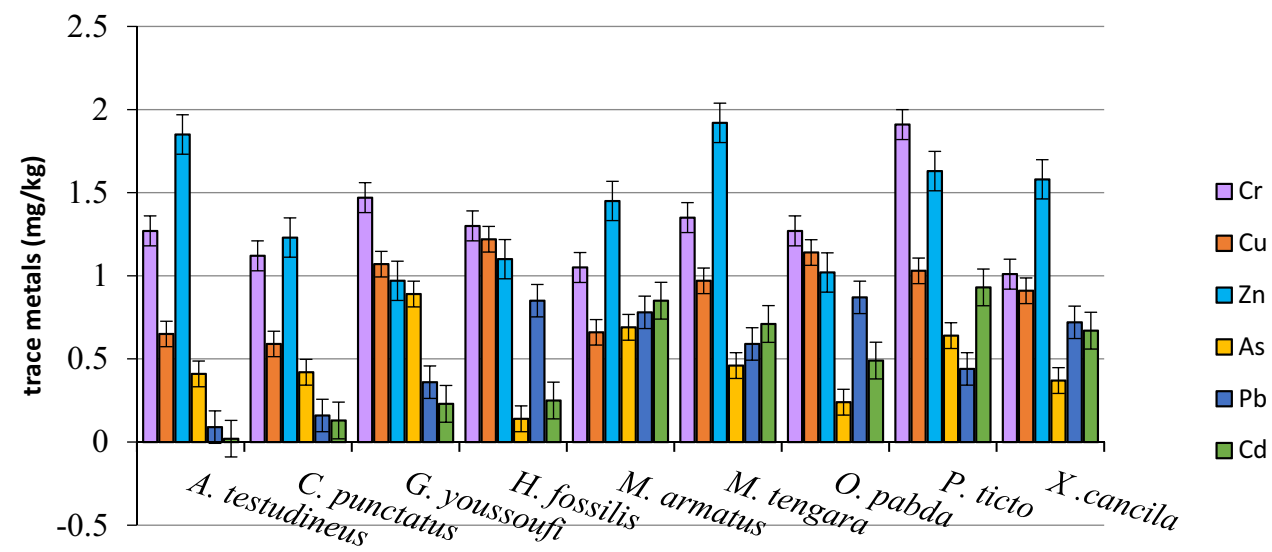

Freshwater native edible fish species 
to our results [48] (Table 3). The appearance of $\mathrm{Cr}$ in foodstuffs actively was involved in lipid and glucose functioning metabolism [49]. However, Cr insufficiency may pose to hinder growth and breakdown of lipid, protein and glucose metabolisms [50]. Also, in extreme cases, it may lead to pulmonary disorders [51] and cause harm in crucial organs such as liver, lungs and kidney [52].

\subsection{Copper (Cu)}

$\mathrm{Cu}$ is an indispensable component and beneficial to health which primarily assists iron to form hemoglobin [53].

However, limitless intake of Cu can vary the liver and kidney performance $[28,42]$. The assessed average concentrations of $\mathrm{Cu}$ in all fish specimens were within the limit provided by the guidelines of MOFL $\left(5.0 \mathrm{mg} \mathrm{kg}^{-1}\right)$ [44], MAFF (Ministry of Agriculture, Fisheries and Food) (30 $\mathrm{mg} \mathrm{kg}^{-1}$ ) [54], the UK Food Standards Committee Report (20.0 $\mathrm{mg} \mathrm{kg}^{-1}$ ) [55] and FAO (70 $\mathrm{mg} \mathrm{kg}^{-1}$ ) [45] (Table 2). The Cu concentration descending order from examined fish species is as follows: $H$. fossilis $\left(1.22 \mathrm{mg} \mathrm{kg}^{-1}\right)>0$. pabda $\left(1.14 \mathrm{mg} \mathrm{kg}^{-1}\right)>$ G. youssoufi $\left(1.07 \mathrm{mg} \mathrm{kg}^{-1}\right)>P$. ticto $\left(1.03 \mathrm{mg} \mathrm{kg}^{-1}\right)>M$. tengara $\left(0.97 \mathrm{mg} \mathrm{kg}^{-1}\right)>X$. cancila $\left(0.91 \mathrm{mg} \mathrm{kg}^{-1}\right)>M$. armatus $\left(0.66 \mathrm{mg} \mathrm{kg}^{-1}\right)>A$. testudineus $\left(0.65 \mathrm{mg} \mathrm{kg}^{-1}\right)>C$. punctatus $\left(0.59 \mathrm{mg} \mathrm{kg}^{-1}\right.$ ) (Fig. 2). It is clearly depicted from the order that the highest $\mathrm{Cu}$ concentration was measured in $H$. fossilis $\left(1.22 \mathrm{mg} \mathrm{kg}^{-1}\right)$, while the least concentration was possessed by $C$. punctatus $\left(0.59 \mathrm{mg} \mathrm{kg}^{-1}\right)$. Although Cu concentration ranged between 3.77 and $6.62 \mathrm{mg} \mathrm{kg}^{-1}$ in Meghna estuary, Noakhali [16], average $1.6 \mathrm{mg} \mathrm{kg}^{-1}$ in another Meghna estuary, Bhola, by examining the same demersal marine species [47]. In addition, Cu concentration ranged between 1.2 and $4.4 \mathrm{mg} \mathrm{kg}^{-1}$ for C. punctatus, H. fossilis and T. fasciata in Turag, Buriganga and Shitalakha Rivers, respectively [48] that exceeded our average (0.92 $\mathrm{mg} \mathrm{kg}^{-1}$ ) findings (Table 4).

Likewise, Mitra et al. [56] documented the Cu ranged between 10 and $100 \mathrm{mg} \mathrm{kg}^{-1}$ in Ganges River which was far beyond (7-88 fold higher approx.) than our results. The maximum recommended level of $\mathrm{Cu}$ for children (1-3 years old) is $1.0 \mathrm{mg} \mathrm{day}^{-1}$, and for adult (19-70 years old), it is $10 \mathrm{mg} \mathrm{day}^{-1}$ [57], and excessive intake may cause liver and kidney damage [58].

\subsection{Zinc (Zn)}

Zn plays a pivotal role in the physiology and metabolic process of several organisms; however, higher concentrations can be toxic and may lead to Parkinson's disease [59]. Among the fishes, $G$. youssoufi showed the lowest mean concentration
(0.97 $\mathrm{mg} \mathrm{kg}^{-1}$ ) and $M$. tengara showed the highest mean concentrations $\left(1.92 \mathrm{mg} \mathrm{kg}^{-1}\right)$. The decreasing order of $\mathrm{Zn}$ for all the fishes is as follows: $M$. tengara $\left(1.92 \mathrm{mg} \mathrm{kg}^{-1}\right)>A$. testudineus $\left(1.85 \mathrm{mg} \mathrm{kg}^{-1}\right)>P$. ticto $\left(1.63 \mathrm{mg} \mathrm{kg}^{-1}\right)>X$. cancila $\left(1.58 \mathrm{mg} \mathrm{kg}^{-1}\right)>M$. armatus $\left(1.45 \mathrm{mg} \mathrm{kg}^{-1}\right)>C$. punctatus $\left(1.23 \mathrm{mg} \mathrm{kg}^{-1}\right)>H$. fossilis $\left(1.1 \mathrm{mg} \mathrm{kg}^{-1}\right)>0$. pabda $\left(1.02 \mathrm{mg} \mathrm{kg}^{-1}\right)>$ G. youssoufi $\left(0.97 \mathrm{mg} \mathrm{kg}^{-1}\right)$ (Fig. 2).

Average $\mathrm{Zn}$ concentration was documented in demersal marine fish species 34, 53, 138 and $31 \mathrm{mg} \mathrm{kg}^{-1}$ in Bhola, Chittagong port, Cox's Bazar and Sundarbans orderly [47]. Nevertheless, the concentration of $\mathrm{Zn}$ in fish specimens in Bangshi River ranged from 42.83 to $371.04 \mathrm{mg} \mathrm{kg}^{-1}$ and 44.35 to $418.05 \mathrm{mg} \mathrm{kg}^{-1}$ in different seasons which extremely exceeded our findings [60] (Table 3). The maximum permissible limit of $\mathrm{Zn}$ in fish and fish product was $100 \mathrm{mg} \mathrm{kg}^{-1}$ proposed by the FAO/WHO [61] and EU (European Union) $30 \mathrm{mg} \mathrm{kg}^{-1}$ [62] (Table 2).

\subsection{Arsenic (As)}

Due to anthropogenic and natural process, As is ubiquitous in the environment. That is why it is difficult to measure the exact quantity and at least $10 \%$ inorganic arsenic contained in total estimation [63]. The lowest mean concentration was $0.14 \mathrm{mg} \mathrm{kg}^{-1}$ on $\mathrm{H}$. fossilis, while the highest mean concentration was $0.89 \mathrm{mg} \mathrm{kg}^{-1}$ in G. youssoufi. The decreasing trends for the examined fish species are as follows: G. youssoufi $\left(0.89 \mathrm{mg} \mathrm{kg}^{-1}\right)>M$. armatus $\left(0.69 \mathrm{mg} \mathrm{kg}^{-1}\right)>P$. ticto $\left(0.64 \mathrm{mg} \mathrm{kg}^{-1}\right)>M$. tengara $\left(0.46 \mathrm{mg} \mathrm{kg}^{-1}\right)>C$. punctatus $\left(0.42 \mathrm{mg} \mathrm{kg}^{-1}\right)>A$. testudineus $\left(0.41 \mathrm{mg} \mathrm{kg}^{-1}\right)>X$. cancila $\left(0.37 \mathrm{mg} \mathrm{kg}^{-1}\right)>0$. pabda $\left(0.24 \mathrm{mg} \mathrm{kg}^{-1}\right)>$ H. fossilis $\left(0.14 \mathrm{mg} \mathrm{kg}^{-1}\right)$ (Fig. 2). As concentrations were varied between 0.75 and $1.48 \mathrm{mg} \mathrm{kg}^{-1}$ in Meghna Estuary, Noakhali [16], while the average concentrations of $0.76 \mathrm{mg} \mathrm{kg}^{-1}$ were estimated in another Meghna Estuary, Bhola [47]. Moreover, As concentration ranged between 0.093 and $0.28 \mathrm{mg} \mathrm{kg}^{-1}$ for $C$. punctatus, $H$. fossilis and T. fasciata in Turag, Buriganga and Shitalakha River, accordingly [48], that was nearly equal or below compared to our findings. Ahmed et al. [16] measured on an average $3.56 \mathrm{mg} \mathrm{kg}^{-1}$ As on body muscle of $C$. striatus, G. giuris and C. garua in Meghna River belonging to the greater Gazaria Upazila which is near to metropolitan areas with highly industrialized avenues (Table 4). Permissible limit for As was set up at $1.0 \mathrm{mg} \mathrm{kg}^{-1}$ by California Environmental Protection Agency (CEPA) [64] and FAO [45]. However, in Bangladesh $5.0 \mathrm{mg} \mathrm{kg}^{-1}$ was permitted as accepted limit by MOFL [44] (Table 2). The seafood stuffs may contain a noteworthy quantity of As in organic form, and those compounds can be directly excreted via urine into the water environment [28]. 
Table 4 Comparisons among the heavy metal concentrations $\left(\mathrm{mg} \mathrm{kg}^{-1}\right)$ in fish muscle from the greater Meghna River and other waters in Bangladesh

\begin{tabular}{|c|c|c|c|c|c|c|c|c|}
\hline \multirow[t]{2}{*}{ River } & \multirow[t]{2}{*}{ Fish species } & \multicolumn{6}{|c|}{$\begin{array}{l}\text { Mean concentrations }\left(\mathrm{mg} \mathrm{kg}^{-1}\right) \text { of heavy } \\
\text { metal }\end{array}$} & \multirow[t]{2}{*}{ References } \\
\hline & & $\mathrm{Cr}$ & $\mathrm{Cu}$ & $\mathrm{Zn}$ & As & $\mathrm{Pb}$ & $\mathrm{Cd}$ & \\
\hline \multirow[t]{4}{*}{ Upper Meghna River and its tributaries } & A. testudineus & 1.27 & 0.65 & 1.85 & 0.41 & 0.09 & 0.02 & \multirow[t]{9}{*}{ Present work } \\
\hline & C. punctatus & 1.12 & 0.59 & 1.23 & 0.42 & 0.16 & 0.13 & \\
\hline & G. youssoufi & 1.47 & 1.07 & 0.97 & 0.89 & 0.36 & 0.23 & \\
\hline & H. fossilis & 1.3 & 1.22 & 1.1 & 0.14 & 0.85 & 0.25 & \\
\hline \multirow[t]{5}{*}{ Chandpur (freshwater pelagic fish) } & M. armatus & 1.05 & 0.66 & 1.45 & 0.69 & 0.78 & 0.85 & \\
\hline & M. tengara & 1.35 & 0.97 & 1.92 & 0.46 & 0.59 & 0.71 & \\
\hline & O.pabda & 1.27 & 1.14 & 1.02 & 0.24 & 0.87 & 0.49 & \\
\hline & P. ticto & 1.91 & 1.03 & 1.63 & 0.64 & 0.44 & 0.93 & \\
\hline & X. cancila & 1.01 & 0.91 & 1.58 & 0.37 & 0.72 & 0.67 & \\
\hline \multirow{8}{*}{$\begin{array}{l}\text { Meghna estuary, Noakhali (marine } \\
\text { demersal fish) }\end{array}$} & Lates calcarifer & 1.19 & 6.62 & - & 1.48 & 4.63 & 0.15 & \multirow[t]{8}{*}{ [16] } \\
\hline & S silondia & 0.95 & 6.26 & - & 1.43 & 4.42 & 0.16 & \\
\hline & Cgarua & 0.77 & 5.83 & - & 1.21 & 4.07 & 0.13 & \\
\hline & P subviridis & 0.67 & 4.94 & - & 0.98 & 3.77 & 0.10 & \\
\hline & Opama & 0.65 & 4.43 & - & 0.84 & 3.37 & 0.09 & \\
\hline & Tilisha & 0.64 & 4.06 & - & 0.82 & 3.33 & 0.10 & \\
\hline & $R$ corsula & 0.62 & 3.83 & - & 0.79 & 2.91 & 0.10 & \\
\hline & A. coila & 0.62 & 3.77 & - & 0.75 & 2.76 & 0.10 & \\
\hline $\begin{array}{l}\text { Meghna estuary, Bhola (marine demer- } \\
\text { sal fish) }\end{array}$ & $\begin{array}{l}\text { T. ilisha, Pampus argentius and Cynoglos- } \\
\text { sus lingua (mean) }\end{array}$ & 0.32 & 1.6 & 34 & 0.76 & 0.25 & 0.051 & [47] \\
\hline Chittagong port & $\begin{array}{l}\text { T. ilisha, Pampus argentius and Cynoglos- } \\
\text { sus lingua (mean) }\end{array}$ & 1.1 & 5.9 & 53 & 2.7 & 0.51 & 0.06 & \\
\hline Cox's Bazar & $\begin{array}{l}\text { T. ilisha, Pampus argentius and Cynoglos- } \\
\text { sus lingua (mean) }\end{array}$ & 2.2 & 14 & 138 & 13 & 0.63 & 0.075 & \\
\hline Sundarbans & $\begin{array}{l}\text { T. ilisha, Pampus argentius and Cynoglos- } \\
\text { sus lingua (mean) }\end{array}$ & 0.15 & 1.3 & 31 & 0.76 & 0.07 & 0.033 & \\
\hline \multirow{5}{*}{$\begin{array}{l}\text { Bangshi River, Savar, Gazipur (a highly } \\
\text { industrialized zone) }\end{array}$} & M. armatus & 0.79 & 26.33 & 309.47 & 2.11 & 2.64 & 0.19 & \multirow[t]{5}{*}[59]{} \\
\hline & P. ticto & 1.93 & 41.91 & 183.64 & 4.33 & 7.36 & 0.39 & \\
\hline & Corica soborna & 0.97 & 23.97 & 418.05 & 3.86 & 9.56 & 0.68 & \\
\hline & M. vittatus & 0.82 & 13.68 & 233.75 & 5.11 & 2.42 & 0.16 & \\
\hline & H. fossilis & 1.14 & 16.04 & 176.98 & 5.64 & 8.29 & 0.46 & \\
\hline \multirow[t]{3}{*}{ Turag River } & C.punctatus & 1.3 & 1.2 & - & 0.093 & 0.13 & - & \multirow[t]{3}{*}[48]{} \\
\hline & H. fossilis & 1.5 & 3.4 & - & 0.14 & 0.65 & - & \\
\hline & Trichogaster fasciata & 2.3 & 2.2 & - & 0.28 & 0.85 & - & \\
\hline \multirow[t]{3}{*}{ Buriganga River } & C.punctatus & 1.4 & 2.7 & - & 0.092 & 0.81 & & \multirow[t]{3}{*}[48]{} \\
\hline & H. fossilis & 2.1 & 4.4 & - & 0.24 & 1.0 & - & \\
\hline & Tfasciata & 2.5 & 4.1 & - & 0.36 & 1.2 & - & \\
\hline \multirow[t]{3}{*}{ Shitalakha river } & C.punctatus & 1.1 & 2.5 & - & 0.12 & 0.16 & - & \multirow[t]{3}{*}[48]{} \\
\hline & H. fossilis & 1.1 & 3.6 & - & 0.22 & 1.0 & - & \\
\hline & Tfasciata & 1.4 & 3.8 & - & 0.22 & 0.69 & - & \\
\hline
\end{tabular}

\subsection{Lead (Pb)}

Among the examined fish species, $A$. testudineus showed the lowest mean concentration $\left(0.09 \mathrm{mg} \mathrm{kg}^{-1}\right)$, whereas O. pabda showed the highest mean concentration $(0.87$ $\left.\mathrm{mgg}^{-1}\right)$. The hierarchy of upward to downward trends was determined as follows: $O$. pabda $\left(0.87 \mathrm{mg} \mathrm{kg}^{-1}\right)>$ H. fossilis $\left(0.85 \mathrm{mg} \mathrm{kg}^{-1}\right)>M$. armatus $\left(0.78 \mathrm{mg} \mathrm{kg}^{-1}\right)>X$. cancila $\left(0.72 \mathrm{mg} \mathrm{kg}^{-1}\right)>M$. tengara $\left(0.59 \mathrm{mg} \mathrm{kg}^{-1}\right)>P$. ticto $\left(0.44 \mathrm{mg} \mathrm{kg}^{-1}\right)>G$. youssoufi $\left(0.36 \mathrm{mg} \mathrm{kg}^{-1}\right)>C$. punctatus 
(0.16 mg kg $\left.\mathrm{mg}^{-1}\right)>$ A. testudineus (0.09 $\mathrm{mg} \mathrm{kg}^{-1}$ ) (Fig. 2). $\mathrm{Pb}$ concentration according to FAO [45] is $0.5 \mathrm{mg} \mathrm{kg}^{-1}$, and Joint Expert Committee on Food Additives (JECFA) [65] permitted up to $3.0 \mathrm{mg} \mathrm{kg}^{-1}$. In Bangladesh, $0.3 \mathrm{mg} \mathrm{kg}^{-1}$ Pd was set as permissible limit by MOFL [44] (Table 2). Ahmed et al. [16] estimated $\mathrm{Pb}$ ranged between 2.76 and $4.63 \mathrm{mg} \mathrm{kg}^{-1}$ for commercial marine fish species in Meghna estuary, Noakhali. Moreover, $\mathrm{Pb}$ concentration ranged between 0.13 and $1.2 \mathrm{mg} \mathrm{kg}^{-1}$ for $C$. punctatus, $H$. fossilis and T. fasciata in Turag, Buriganga and Shitalakha River, respectively [48] (Table 4) that was slightly equal or higher than our assessment.

\subsection{Cadmium (Cd)}

The lowest and the highest mean of $\mathrm{Cd}$ in fishes was found as $0.02 \mathrm{mg} \mathrm{kg}^{-1}$ and $0.93 \mathrm{mg} \mathrm{kg}^{-1}$ in A. testudineus and $P$. ticto, respectively. The hierarchy trends are as follows: $P$. ticto $\left(0.93 \mathrm{mg} \mathrm{kg}^{-1}\right)>M$. armatus $\left(0.85 \mathrm{mg} \mathrm{kg}^{-1}\right)>M$. tengara $\left(0.71 \mathrm{mg} \mathrm{kg}^{-1}>X\right.$. cancila $\left(0.67 \mathrm{mg} \mathrm{kg}^{-1}\right)>0$. pabda $\left(0.49 \mathrm{mg} \mathrm{kg}^{-1}\right)>H$. fossilis $\left(0.25 \mathrm{mg} \mathrm{kg}^{-1}>G\right.$. youssoufi $\left(0.23 \mathrm{mg} \mathrm{kg}^{-1}\right)>C$. punctatus $\left(0.13 \mathrm{mg} \mathrm{kg}^{-1}\right)>A$. testudineus $\left(0.02 \mathrm{mg} \mathrm{kg}^{-1}\right)$. Cd was documented $0.018 \mathrm{mg} \mathrm{kg}^{-1}$, $0.036 \mathrm{mg} \mathrm{kg}^{-1}$ and $0.05 \mathrm{mg} \mathrm{kg}^{-1}$ from Turag, Shitalakha and Buriganga River, respectively [48]. Ahmed et al. [16] reported that $\mathrm{Cd}$ ranged between 0.16 and $0.10 \mathrm{mg} \mathrm{kg}^{-1}$ in Meghna River estuary, Noakhali region, from the marine commercial fish. In another study, $\mathrm{Cd}$ ranged between 0.1 and $4.4 \mathrm{mg} \mathrm{kg}^{-1}$ in Meghna estuary, Gazaria Upazila (a highly industrial city), from the edible muscle of $C$. striatus, G. giuris and C. garua [66]. An average concentration of $C d$ was $0.06 \mathrm{gmkg}^{-1}, 0.075 \mathrm{mg} \mathrm{kg}^{-1}$ and $0.033 \mathrm{mg} \mathrm{kg}^{-1}$ which was estimated in Chittagong port, Cox's Bazar and Sundarbans from marine commercial fish species accordingly [47] (Table 4). An acceptance limit for $\mathrm{Cd}\left(0.1 \mathrm{mg} \mathrm{kg}^{-1}\right)$ was set up by FAO [45] and WHO [46]. In Bangladesh, Cd permissible limit was $0.25 \mathrm{mg} \mathrm{kg}^{-1}$ established by MOFL [44] (Table 2).

\section{Statistical interpretation}

The concentration of trace metals has been depicted on the bar graph (Fig. 2). The graph clearly shows how the amount of trace metals $\left(\mathrm{mg} \mathrm{kg}^{-1}\right)$ was possessed by freshwater native fish species. For example, the maximum concentrations of $\mathrm{Zn}(>1.5)$ was possessed by $A$. testudineus, $M$. tengara, $P$. ticto and $X$. cancila. On the contrary, least $\mathrm{Pb}$ $(<0.5)$ concentrations was possessed by $A$. testudineus, $C$. punctatus, G. youssoufi and P. ticto (Fig. 2).

From the correlation analysis, both positive and negative correlations were noticed, where the positive relations indicated that the metals originated from same source and negative relations denoted the source of metals from different sources. For example, $\mathrm{Cu}-\mathrm{Pb}(0.56)$ and $\mathrm{Pb}-\mathrm{Cd}(0.54)$ were positively correlated at $p<0.05$ level of significance. However, $\mathrm{Pd}-\mathrm{Zn}(-0.36)$ was negatively correlated with each other (Table 3).

Principal Component Analysis (PCA) and the Eigenvalues were presented and the components from left to right direction in the scree plot along with variance (Fig. 3a). Also, the percentage (\%) of eigenvalues and the variance in components 1 (eigenvalue: 0.16582, variance: 33.074) and 2 (eigenvalue: 0.1633 , variance: 32.572 ) were closely related and maintained almost same slope (inset in Fig. 3a). However, it slopes downward with changing both the eigenvalues and variance stopped at components 6 (inset in Fig. 3a). The correlation matrix (variance-covariance) indicated that the components 2,3,4, 5 and 6 were correlated with the component 1 . It means all the trace metals were measured in the same units $\left(\mathrm{mg} \mathrm{kg}^{-1}\right)$. Furthermore, the dash-dot line denoted the deviation of variance from the ideal range.

From the loading plot of bar graph, it is indicated that all the heavy metals are positively correlated with each other except for $\mathrm{Cu}$ and $\mathrm{Pb}$, and this is negatively correlated (Fig. $3 \mathrm{~b}$ ). In addition, the rotated PCA plot transparently showed that the $\mathrm{Zn}, \mathrm{As}, \mathrm{Cd}$ and $\mathrm{Cr}$ were the major contributors in the collected freshwater indigenous fish from the selected areas. Moreover, these metals were tending to concentrate more on $M$. armatus, P. ticto, $X$. cancila and M. tengara, A. testudineus, C. punctatus (Fig. 3C), whereas $O$. pabda, H. fossilis and $G$. youssoufi were tending to be gradually affected by $\mathrm{Pb}$ and $\mathrm{Cu}$ (Fig. $3 \mathrm{C}$ ).

The loading bar chart depicts which trace metals were significantly dominant on the fish specimens (Fig. 3b).

The dendrogram showed the distance (Euclidean) among heavy metals closeness/distance to each other in the clusters (Fig. 3d). The closest metals were $\mathrm{Zn}$ and $\mathrm{Cr}$ belonged to cluster 2 . On the other hand, cluster 1 was subdivided into $\mathrm{Cu}$ and then in $\mathrm{As}$, and finally, $\mathrm{Pd}$ and $\mathrm{Cd}$ belonged to the same clades which means they were closely related and originated from same source (Fig. 3d).

\section{Non-carcinogenic and carcinogenic health risk assessment}

\subsection{Estimated daily intake}

EDIs were explored from selected toxic trace metals on fish consumption by average coastal Bangladeshi both adults and children documented in Table 2. In addition, EDI was calculated emphasizing the oral reference dose (RfD) for a specific chemical that elaborated the everyday exposition to noxious components that avoids any deleterious 
$\mathbf{A}$

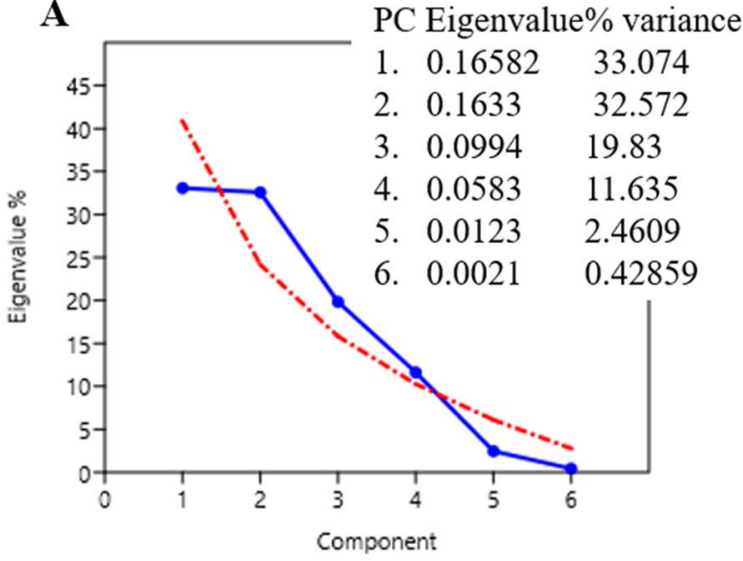

C

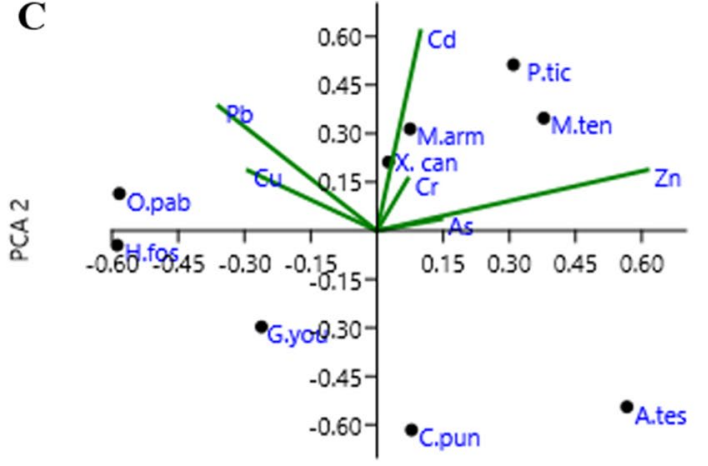

PCA 1

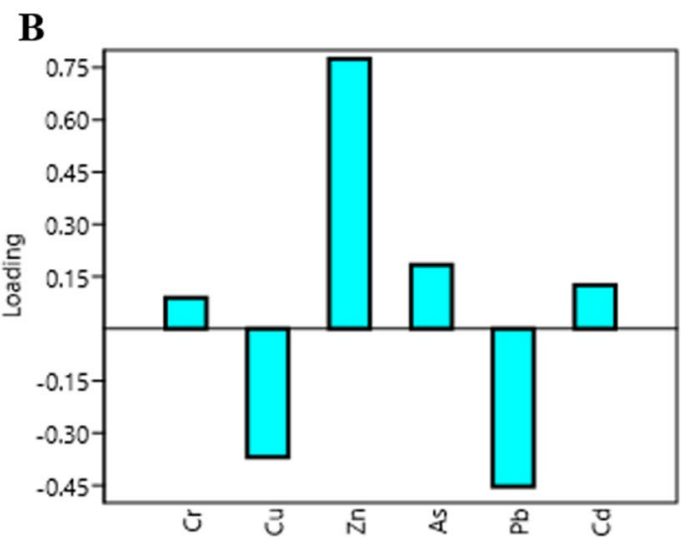

D

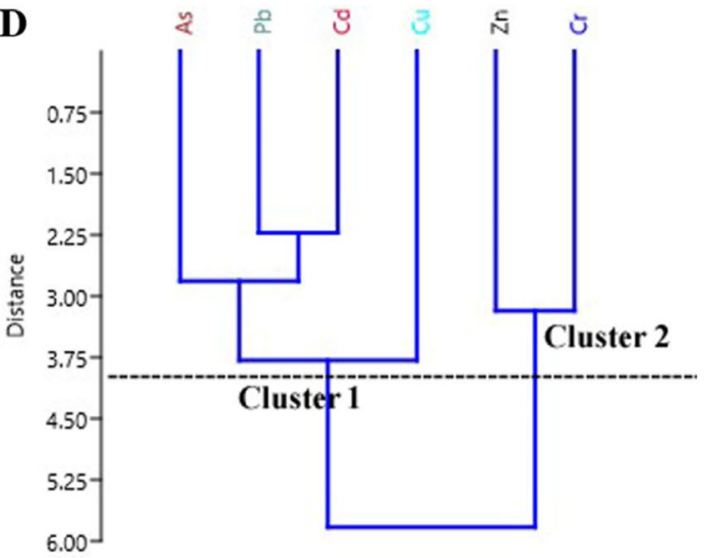

of six metals directly affected the fish species. $\mathbf{d}$ Hierarchical cluster analysis (dendrogram) of trace metals in the study area (Ward linkage method)

than PDA/RfD [28]. For example, if the outputs were far below than the recommended PDA (Table 2), metals might undergo a maximum assimilation in fish muscle accumulation in fish tissue that cause health risk in the future, in the long run; hence, the continuous monitoring would be necessary

\subsection{Non-carcinogenic and carcinogenic risk}

The THQ was analyzed to predict the non-carcinogenic risk, and the acceptable threshold limit was 1, recommended by USEPA [67]. If the THQ value $<1$, then it indicated that there is lower or no non-carcinogenic risk for the consumers, whereas there might have a derogative effects to the consumers if it exceeds the recommended limits.

The estimated THQ values showed that the threshold was less than one $(<1.0)$ for both adult and children (Table 5). None of a single metal exceeded the guidelines for all fish species. It also indicated that the children are more susceptible to non-carcinogenic risk than the adult people. However, able limit' and 'unacceptable limit,' based on doses lower 


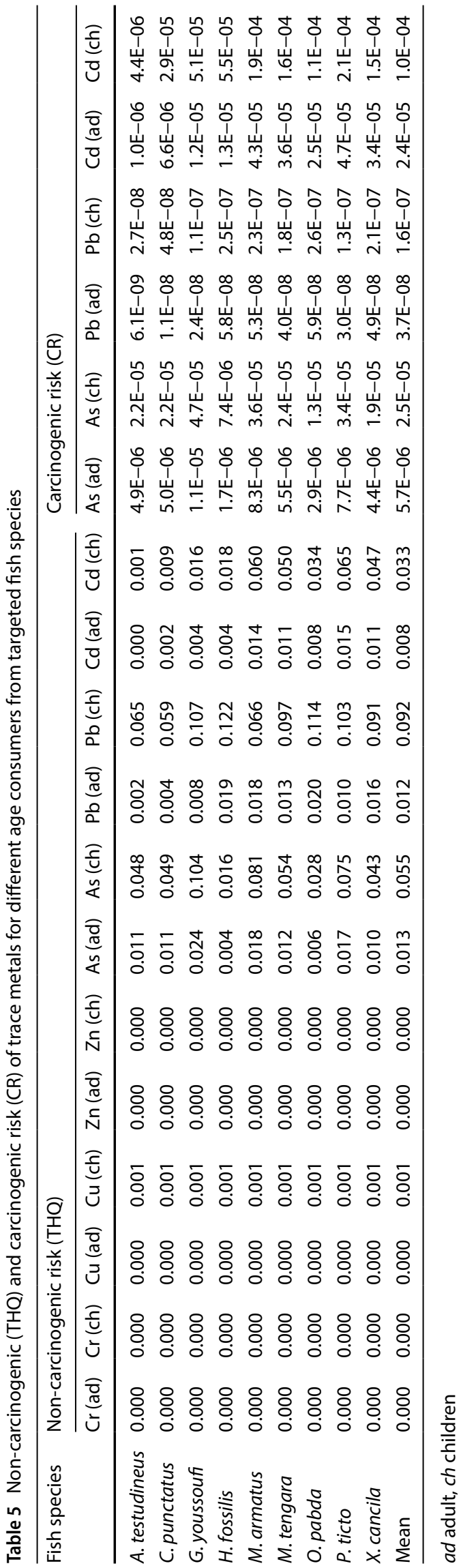

due to the lack of absolute dose relationship, THQ cannot be recommended as direct estimation of risk concern [68].

Carcinogenic risk (CR) of As, Pd and Cd was estimated (Table 5) for all the collected fish species. The calculated average value of $\mathrm{CR}$ for $\mathrm{As}, \mathrm{Pb}$ and $\mathrm{Cd}$ was 5.7E-06, 3.7E-08 and $2.4 \mathrm{E}-05$ for adult, while it was $2.5 \mathrm{E}-05,1.6 \mathrm{E}-07$ and $1.0 \mathrm{E}-04$ for children, accordingly (Table 5 ). $C R$ values which are lower than $10^{-6}$ were counted as negligible, whereas the values above $10^{-4}$ were considered as deleterious effects for human health [30,37]. CR values indicated that the children are more susceptible to carcinogenic risk than the adults. In our study, the calculated CR values were at minimal level for adult, whereas the children were exposed to below and equal to $10^{-4}\left(\leq 10^{-4}\right)$ which might exceed the accepted range in near future. Although the $C R$ values were within the limit for both children and adult, however, a prolong exposure to heavy metals might negatively affect both sexes. Our results were in agreement with the previous studies $[16,47$, 49].

Overall, the heavy metals concentrations in the selected areas did not exceed the recommended limits stated by national and international agencies except for $\mathrm{Cr}$. Compiling from other studies, it seemed that the concentrations of $\mathrm{Cr}$ often exceeded the permissible limits from its adjacent rivers. Although EDI, THQ and CR values were at minimal levels, a continuous monitoring with its possible bioremediation would be a potential solution for the consumers.

Therefore, the bioremediation of these heavy metals from the selected areas might be a potential solution to step down the contamination level as future perspectives. Several biological approaches such as agricultural wastes, peat, algae, fungi, bacteria, yeasts and cellular products [72-74] have been experimented and documented the uptake of heavy metals. Ideally, some microalgae such as Chlamydomonas reinhardtii, Chlorella vulgaris, Phormidium ambiguum, Pseudochlorococcum typicum, Scenedesmus obliquus and Scenedesmus quadricauda var quadrispina can be treated to control or remove the contamination of $\mathrm{Zn}$, $\mathrm{Cu}, \mathrm{Pb}$ and $\mathrm{Cd}$ [75-77]. Apart from those algae, bacterial isolates, e.g., Acinetobacter sp., Arthrobacter sp., Bacillus sp., Gemella sp., Micrococcus sp., Hafnia sp., Proteus mirabilis strain ALK428, Pseudomonas sp., Pseudomonas aeruginosa strain Pse12, have been identified as effective remediator for $\mathrm{Zn}, \mathrm{Cu}, \mathrm{Pb}, \mathrm{Cr}, \mathrm{Cd}$ and As [78-80] that might be a suitable and economic technique for the country's point of view. 


\section{Conclusion and future perspectives}

The study was conducted in the Meghna River and its associated tributaries diluted with Padma River in Chandpur and flowed downward to Mehendiganj, Barisal district. As this river is directly connected to the metropolitan city at upstream and finally diluted in the Bay of Bengal, metals were detected throughout the river. Among the assessed metals, $\mathrm{Zn}\left(1.92 \mathrm{mg} \mathrm{kg}^{-1}\right)$ showed the maximum concentrations in $M$. tengara, but did not exceed the guidelines suggested by national (MOFL) and international agencies (WHO, FAO, USEPA, etc.). However, the second highest concentrations were documented as $\mathrm{Cr}\left(1.91 \mathrm{mg} \mathrm{kg}^{-1}\right)$ on P. ticto which surpassed the recommended guidelines provided by national and international organizations. A positive correlations were noticed between $\mathrm{Cu}-\mathrm{Pb}(r=0.56)$ and $\mathrm{Pb}-\mathrm{Cd}$ $(r=0.54)(p<0.05)$ from the selected metals. $\mathrm{Zn}, \mathrm{Cr}, \mathrm{Cd}$ and As showed the most significant relationship with $M$. armatus, $M$. tengara, $P$. ticto and $X$. cancila. The THQ was evaluated both for children and adult consumers and revealed none of them experienced non-carcinogenic health effects. Furthermore, the calculated $C R$ values were less and equal to the threshold limits $\left(10^{-4}\right)$ which denotes that the $C R$ values were safe to all the consumers. Nevertheless, the study emphasizes the children as they are more susceptible to carcinogenic and non-carcinogenic than the adults.

Acknowledgements The authors are deeply thankful to the laboratory in Forensic Analysis Department, RAB (Rapid Action Battalion) Head Quarter, Bangladesh, for providing all necessary research facilities. The authors also thank Abdul Matin for his contribution in sampling. This research received very small financial support but not as grant from the Noakhali Science and Technology University to promote research in higher studies through research cell of the university in 2018.

Authors contributions [MdJS] contributed to conceptualization, resources and writing - review and editing; [MdJS], [MdAI], [AUP], [NNR] and [TF] were involved in methodology; [MdJS], [MdAl] and [AUP] contributed to formal analysis, investigation and writingoriginal draft preparation; and [MdJS] was involved in funding acquisition and supervision.

Funding This study did not receive any grants from potential sources.

\section{Compliance with ethical standards}

Conflict of interest All the authors have declared that there is no conflict of interest that would be perceived as impartiality of the research reported.

Ethical approval This article does not contain any studies with human participants performed by any of the authors, while all applicable international, national and/or institutional guidelines for the care and use of animals were followed.

\section{References}

1. Islam MS, Han S, Ahmed MK, Masunaga S (2014) Assessment of trace metal contamination in water and sediment of some rivers in Bangladesh. J Water Environ Technol 12:109-121

2. Gan Y, Wang L, Yang G, Dai J, Wang R, Wang W (2017) Multiple factors impact the contents of heavy metals in vegetables in high natural background area of China. Chemosphere 184:1388-1395

3. Hossain MB, Ahmed ASS, Sarker MSI (2018) Human health risks of $\mathrm{Hg}, \mathrm{As}, \mathrm{Mn}$, and $\mathrm{Cr}$ through consumption of fish, Ticto barb (Puntius ticto) from a tropical river, Bangladesh. Environ Sci Pollut Res Int 25(31):31727-31736

4. Hajeb $P$, Jinap $S$, Ismail $A$, Fatimah $A B$, Jamilah $B$, Rahim MA (2009) Assessment of mercury level in commonly consumed marine fishes in Malaysia. Food Control Bull 131:356-364

5. Yi Y, Yang Z, Zhang S (2011) Ecological risk assessment of heavy metals in sediment and human health risk assessment of heavy metals in fishes in the middle and lower reaches of the Yangtze River basin. Environ Pollut 159:2575-2585

6. Hezbullah M, Sultana S, Chakraborty SR, Patwary M (2016) Heavy metal contamination of food in a developing country like Bangladesh: an emerging threat to food safety. J Toxicol Environ Health Sci 8(1):1-5

7. Ahmed ATB, Mandal S, Chowdhury DA, Rayhan MA, Tareq RM (2012) Bioaccumulation of some heavy metals in Ayre Fish (Sperata Aor Hamilton, 1822), sediment and water of Dhaleshwari River in dry season, Bangladesh. J Zool 40:147-153

8. Chakraborty P, Babu PR, Acharyya T, Bandyopadhyay D (2010) Stress and toxicity of biologically important transition metals (Co, $\mathrm{Ni}, \mathrm{Cu}$ and $\mathrm{Zn}$ ) on phytoplankton in a tropical freshwater system: an investigation with pigment analysis by HPLC. Chemosphere 80(5):548-553

9. Mansour SA, Sidky MM (2002) Heavy metals contaminating water and fish from Fayoum Governorate, Egypt. Food Chemosphere 78:15-22

10. Ahmed MK, Baki MA, Kundu GK, Islam MS, Islam MM, Hossain MM (2016) Human health risks from heavy metals in fish of Buriganga river, Bangladesh. Springer Plus 5:1697

11. Wei Y, Zhang J, Zhang D, Tu T, Luo L (2014) Metal concentrations in various fish organs of different fish species from Poyang Lake, China. Ecotoxicol Environ Saf 104:182-188

12. Rahman MS, Islam MR (2010) Adsorption of Cd(II) ions from synthetic waste water using maple sawdust. Energy Sources Part A Recov Util Environ Effects 32:222-231

13. Ashraf SA, Adnan M, Patel M, Siddiqui AJ, Sachidanandan M, Snoussi M, Hadi S (2020) Fish-based bioactives as potent nutraceuticals: exploring the therapeutic perspective of sustainable food from the sea. Mar Drugs 18(5):265

14. Khalili Tilami S, Sampels S (2018) Nutritional value of fish: lipids, proteins, vitamins, and minerals. Rev Fish Sci Aquacult 26:243-253

15. Marques I, Botelho G, Guiné R (2019) Comparative study on nutritional composition of fish available in Portugal. Nutr Food Sci 49:925-941

16. Ahmed ASS, Rahman M, Sultan S, Babu SMOF, Sarker MSI (2019) Bioaccumulation and heavy metal concentration in tissues of some commercial fishes from the Meghna River Estuary in Bangladesh and human health implications. Mar Poll Bull 145:436-447

17. Bhuyan S, Islam S (2016) Present status of socio-economic conditions of the fishing community of the Meghna River Adjacent to Narsingdi District, Bangladesh. J Fish Livest Product 4:1-5 
18. Hassan M, Rahman MATMT, Saha B, Kamal AKI (2015) Status of heavy metals in water and sediment of the Meghna River, Bangladesh. Am J Environ Sci 11(6):427-439

19. Traina A, Bono G, Bonsignore $M$, Falco F, Giuga M, Quinci EM, Sprovieri M (2019) Heavy metals concentrations in some commercially key species from Sicilian coasts (Mediterranean Sea): potential human health risk estimation. Ecotoxicol Environ Saf 168:466-478

20. Batista BL, Nacano LR, de Freitas R, de Oliveira-Souza VC, Barbosa F (2012) Determination of essential (Ca, Fe, I, K, Mo) and toxic elements $(\mathrm{Hg}, \mathrm{Pb})$ in Brazilian rice grains and estimation of reference daily intake. Food Nutr Sci 3:129

21. USEPA (2000) Guideline for assessing chemical contaminant data for use in fish advisories, vol. I: fish sampling and analysis, 3 edn. Office of Water. U.S. Environmental Protection Agency, Washington, DC (Document No. EPA 823-B-00007. November 2000)

22. USEPA (2000) Methodology for deriving ambient water quality criteria for the protection of human health (EPA822-B-00-004), Washington, DC, USA

23. USEPA (2000) Risk-based concentration table. United States Environmental Protection Agency, Washington

24. Griboff J, Wunderlin DA, Monferran MV (2017) Metals, As and Se determination by inductively coupled plasma-mass spectrometry (ICP-MS) in edible fish collected from three eutrophic reservoirs. Their consumption represents a risk for human health. Microchem J 130:236-244

25. Varol M, Kaya GK, Alp A (2017) Heavy metal and arsenic concentrations in rainbow trout (Oncorhynchus mykiss) farmed in a dam reservoir on the Firat (Euphrates) River: risk-based consumption advisories. Sci Total Environ 599:1288-1296

26. USEPA (2008a) Environmental Protection Agency. Integrated Risk Information System. CRC

27. USEPA (2008b) Integrated risk information system. United States Environmental Protection Agency, Washington, DC, USA. https://www.epa.gov/iris. Accessed 5 May 2020

28. Baki MA, Hossain MM, Akter J, Quraishi SB, Shojib MFH, Ullah $A A$, Khan MF (2018) Concentration of heavy metals in seafood (fishes, shrimp, lobster and crabs) and human health assessment in Saint Martin island, Bangladesh. Ecotoxicol Environ Saf 159:153-163

29. Heshmati A, Ghadimi S, Khaneghah AM, Barba FJ, Lorenzo JM, Nazemi F, Fakhri Y (2018) Risk assessment of benzene in food samples of Iran's market. Food Chem Toxicol 114:278-284

30. USEPA (2010) Integrated Risk Information System (IRIS). United States Environmental Protection Agency, Washington, DC, USA. https://www.epa.gov/iris/basic-information-about-integ rated-risk-information-system\#iniris. Accessed 6 Aug 2020

31. Abtahi M, Fakhri Y, Oliveri CG, Keramati H, Zandsalimi Y, Bahmani Z, Ghasemi SM (2017) Heavy metals (As, Cr, Pb, Cd and Ni) concentrations in rice (Oryza sativa) from Iran and associated risk assessment: a systematic review. Toxin Rev 36:331-341

32. Wang X, Sato T, Xing B, Tao S (2005) Health risks of heavy metals to the general public in Tianjin, China via consumption of vegetables and fish. Sci Total Environ 350(1-3):28-37

33. Zhong W, Zhang Y, Wu Z, Yang R, Chen X, Yang J, Zhu L (2018) Health risk assessment of heavy metals in freshwater fish in the central and eastern North China. Ecotoxicol Environ Saf 157:343-349

34. Li J, Huang ZY, Hu Y, Yang H (2013) Potential risk assessment of heavy metals by consuming shellfish collected from Xiamen, China. Environ Sci Pollut Res 20(5):2937-2947

35. FAO (2014) The State of the World Fisheries and Aquaculture. FAO Fisheries and Aquaculture Dept
36. Yin S, Feng C, Li Y, Yin L, Shen Z (2015) Heavy metal pollution in the surface water of the Yangtze Estuary: a 5-year follow-up study. Chemosphere 138:718-725

37. USEPA (2010) Risk-based concentration table. http://www.epa. gov/reg3hwmd/risk/human/index.htm

38. Hu B, Jia X, Hu J, Xu D, Xia F, Li Y (2017) Assessment of heavy metal pollution and health risks in the soil-plant-human system in the Yangtze river delta, China. Int J Adv Technol Eng Res 14:1042

39. USEPA (1989) Risk assessment guideline for superfund volume 1 human evaluation manual (Part A) 291

40. Gu YG, Huang HH, Lin Q (2016) Concentrations and human health implications of heavy metals in wild aquatic organisms captured from the core area of Daya Bay's Fishery Resource Reserve, South China Sea. Environ Toxicol Pharmacol 45:90-94

41. Cao S, Duan X, Zhao X, Ma J, Dong T, Huang N, Wei F (2014) Health risks from the exposure of children to $\mathrm{As}, \mathrm{Se}, \mathrm{Pb}$ and other heavy metals near the largest coking plant in China. Sci Total Environ 472:1001-1009

42. Vu CT, Lin C, Yeh G, Villanueva MC (2017) Bioaccumulation and potential sources of heavy metal contamination in fish species in Taiwan: assessment and possible human health implications. Environ Sci Pollut Res 24:19422-19434

43. Vieira C, Morais S, Ramos S, Delerue-Matos C, Oliveira MBPP (2011) Mercury cadmium, lead and arsenic levels in three pelagic fish species from the Atlantic Ocean: intra and interspecific variability and human health risks for consumption. Food Chem Toxicol 49:923-932

44. MOFL (2014) Bangladesh Gazette, Bangladesh Ministry of Fisheries and Livestock, SRO no. 233/Ayen

45. FAO (1983) Compilation of legal limits for hazardous substances in fish and fishery product. 746. Library (Lond) 104

46. WHO (2004) Guidelines for drinking water quality, 3rd edn. World Health Organization, Geneva

47. Raknuzzaman $M$, Ahmed MK, Islam MS, Habibullah-Al-Mamun M, Tokumura M, Sekine M, Masunaga S (2016) Trace metal contamination in commercial fish and crustaceans collected from coastal area of Bangladesh and health risk assessment. Environ Sci Pollut Res 23:17298-17310

48. Islam MS, Ahmed MK, Habibullah-Al-Mamun M, Masunaga S (2015) Assessment of trace metals in fish species of urban rivers in Bangladesh and health implications. Environ Toxicol Pharmcol 39:347-357

49. Saha N, Mollah MZI, Alam MF, Rahman MS (2016) Seasonal investigation of heavy metals in marine fishes captured from the Bay of Bengal and the implications for human health risk assessment. Food Control 70:110-118

50. Calabrese EJ, Canada AT, Sacco C (1985) Trace elements and public health. Annu Rev Public Health 6(1):131-146

51. Forti E, Salovaara $S$, Cetin $Y$, Bulgheroni A, Tessadri R, Jennings $P$, Prieto $P(2011)$ In vitro evaluation of the toxicity induced by nickel soluble and particulate forms in human airway epithelial cells. Toxicol In Vitro 25:454-461

52. Alipour H, Pourkhabbaz A, Hassanpour M (2015) Estimation of potential health risks for some metallic elements by consumption of fish. Water Qual Exp Health 7(2):179-185

53. Hart EB, Steenbock H, Waddell J, Elvehjem CA (2002) Iron in nutrition: VII. Copper as a supplement to iron for hemoglobin building in the rat. J Biol Chem 277(34):e22

54. MAFF (1995) Monitoring and surveillance of non-radioactive contaminants in the aquatic environment and activities regulating the disposal of wastes at sea, 1993. Aquatic Environment Monitoring Report No. 44. Directorate of Fisheries Research, Lowestoft

55. Cronin L, Guyatt G, Griffith L, Wong E, Azziz R, Futterweit W, Dunaif A (1998) Development of a health-related quality-of-life 
questionnaire (PCOSQ) for women with polycystic ovary syndrome (PCOS). J Clin Endocrinol Metab 83:1976-1987

56. Mitra A, Chowdhury R, Banerjee K (2012) Concentrations of some heavy metals in commercially important finfish and shellfish of the River Ganga. Environ Monit Assess 184(4):2219-2230

57. IOM (2003) Dietary reference intakes: applications in dietary planning. Subcommittee on Interpretation and Uses of Dietary Reference Intakes and the Standing Committee on the Scientific Evaluation of Dietary Reference Intakes. Institute of Medicine of the National Academies, The National Academies Press, Washington, DC, pp 248

58. ATSDR (2004) Agency for Toxic Substances and Disease Registry, Division of Toxicology, Clifton Road, NE, Atlanta, GA

59. Gorell JM, Johnson CC, Rybicki BA, Peterson EL, Kortsha GZ, Brown GG (1997) Occupational exposures to metals as risk factors for Parkinson's disease. Neurology 48:650-658

60. Rahman MS, Molla AH, Saha N, Rahman A (2012) Study on heavy metals levels and its risk assessment in some edible fishes from Bangshi River, Savar, Dhaka, Bangladesh. Food Chem 134:1847-1854

61. FAO/WHO (1989) Evaluation of certain food additives and the contaminants mercury, lead and cadmium. Technical Report Series 505

62. EU (2001) Commission regulation n. 221/2002 of the 6 February 2002 amending regulation (EC) n. 466/2002 setting maximum levels for certain contaminants in foodstuffs, Official Journal of the European Communities. Brussels (2002)

63. USFDA (1993) Guidance document for arsenic in shellfish. U.S. Food and Drug Administration, Washington, pp 25-27

64. CEPA (1995-97) California Environmental Protection Agency, State Water Resources

65. JECFA (2000) Evaluation of certain food additives and contaminants. Fifty-third Report of the Joint FAO/WHO Expert Committee on Food Additives. (WHO Technical Report Series, No. 896). World Health Organization, Geneva

66. Ahmed MK, Ahamed S, Rahman S, Haque MR, Islam MM (2009) Heavy metals concentration in water, sediments and their bioaccumulations in some freshwater fishes and mussel in Dhaleshwari River, Bangladesh. Terres Aquat Environ Toxicol 3:33-41

67. USEPA (2011) USEPA Regional Screening Level (RSL) Summery Table

68. USEPA (1989) Guidance manual for assessing human health risk from chemically contaminated, fish and shellfish (EPA-503/8-89002). USEPA, Washington DC
69. FAO (2000) Food and Agriculture Organization of the United Nations Rome

70. WHO (1996) Guidelines for drinking water quality, vol 2, 2nd edn. World Health Organization, Geneva

71. FAO (2006) Arsenic contamination of irrigation water, soil and crops in Bangladesh: risk implications for sustainable agriculture and food safety in Asia. Food and agriculture organization of the United Nations regional office for Asia and the Pacific, Bangkok

72. Gavrilescu M (2004) Removal of heavy metals from the environment by biosorption. Eng Life Sci 3:219-232

73. Demirbas A (2008) Heavy metal adsorption onto agrobased waste materials: a review. J Hazard Mater 157:220-229

74. Lupea M, Bulgariu L, Macoveanu M (2012) Biosorption of Cd(II) from aqueous solution on marine green algae biomass. Environ Eng Manag J 11:607-615

75. Gokhale SV, Jyoti KKSS, Lele SS (2008) Kinetic and equilibrium modeling of chromium( $(\mathrm{VI})$ biosorption on fresh and spent Spirulina platensis/Chlorella vulgaris biomass. Bioresour Technol 99:3600-3608

76. Nasreen K, Muhammad I, lqbal ZS, Javed I (2008) Biosorption characteristics of unicellular green alga Chlorella sorokiniana immobilized in loofa sponge for removal of $\mathrm{Cr}(\mathrm{III})$. J Environ Sci 20:231-239

77. Sanaa S, Essa A, Shalaby E (2012) Bioremoval capacity of three heavy metals by some microalgae species (Egyptian Isolates). Plant Signal Behav 7(3):392-399

78. Jayabarath J, Shyam SS, Arulmurugan R, Giridhar R (2009) Bioremediation of heavy metals using biosurfactants. Int J Biotechnol Appl 1(2):50-54

79. Marzan LW, Hossain M, Mina SA, Akter Y, Chowdhury AMMA (2017) Isolation and biochemical characterization of heavymetal resistant bacteria from tannery effluent in Chittagong city, Bangladesh: bioremediation viewpoint. Egypt J Aquat Res 43:65-74

80. Nupur SH, Rayhan A, Ahmed S (2020) Bacteria with heavy metal bioremediation potential isolated from the polluted river water of Bangladesh. J Biotechnol Biochem 6(1):06-14

Publisher's Note Springer Nature remains neutral with regard to jurisdictional claims in published maps and institutional affiliations. 